\title{
Web Based GIS for Tourism Development Using Effective Free and Open Source Software Case Study: Gondor Town and Its Surrounding Area, Ethiopia
}

\author{
Mengesha Endalew Zerihun \\ Department of Civil Engineering, Debre Markos University, Debre Markos, Ethiopia \\ Email: mengeyene@yahoo.com
}

How to cite this paper: Zerihun, M.E. (2017) Web Based GIS for Tourism Development Using Effective Free and Open Source Software Case Study: Gondor Town and Its Surrounding Area, Ethiopia. Journal of Geographic Information System, 9, 47-58.

https://doi.org/10.4236/jgis.2017.91004

Received: December 28, 2016

Accepted: February 25, 2017

Published: February 28, 2017

Copyright $\odot 2017$ by author and Scientific Research Publishing Inc. This work is licensed under the Creative Commons Attribution International License (CC BY 4.0).

http://creativecommons.org/licenses/by/4.0/

\section{c) (i) Open Access}

\begin{abstract}
Tourism in developing countries are some means of solving their economic problems and improving live standards of people and creates job opportunity for the host people in getting additional income and improve the developments of the country. The result of tourism in terms of environmental, cultural, economic and social aspects has a greater effect for Ethiopia. Gondar, the center of Ethiopian art and culture, is famous in its many Imperial castles and the design and decoration of its churches. This land of castles and churches was founded by Emperor Fasiladas in 1930s and served as tourist attraction sites all over the world. The main challenge to attract international tourists in the study area is Scarce and insufficient promotion of the tourist attraction sites, Lack of broad information based on the internet about tourism information, and lack of organized information about tourism facilities \& destinations. This study tries to identify tourist attraction elements of Gondor town and its surrounding area $\&$ to identify non spatial data's essential for touristic activities to develop \& propose a web based GIS portal for the improvement of tourism activity in the town. The main target of developing a web based GIS interactive map is to promote and improve tourism industry of the area. It has been produced using free and open source software's for fast processing, displaying, sharing, and distribution of tourism information using world wide web. For the web services PHP, HTML script language and QGIS2leaflet plugins are used in the development of web GIS portal.
\end{abstract}

\section{Keywords}

Web Based GIS, Tourism, Gondor, QGIS, Free and Open Source Softwares 


\section{Introduction}

Web GIS is the process of designing, implementing, generating and delivering maps on the World Wide Web by combining both the advantage of GIS and the internet [1]. GIS integrates and relates data with spatial component and supports users to view in proper format which supports in making complex spatial decisions through visualization, interactive modelling and analysis environments [13].

A web GIS is a GIS application made available through a common web browser. Together with the use of the World Wide Web, GIS could be further developed to allow many more people to have access to GIS functionality and to enhance community participation in planning [3]. Web-based GIS, an extension of Geographic Information System (GIS), consists of four major system components which include client for sending request through web browser, web server with application server for responding to the request, map server and data server [4]. The above four components would be integrated to develop web based GIS portal for Gondor town and its surrounding area. Web based GIS is being one of the newest fields in Geographic Information systems for web based map creation. Different software and technologies are used to develop in web mapping using commercial, open source and public software [10]. For Commercial purposes commercial companies develop well documented and licensed software that contain advance features but the price for that technology is high relative to open source software. Open source software system is developing rapidly with the involvement of large number of people and can be used free of charge by having poor documentation.

Ethiopia is a land of origin and friendly people [1] who are conscious of its historical, cultural and natural heritages [2]. It is also a land of contrasts and surprises, of remote and wild places, home to cultured people who are descended from some of the world's oldest civilizations [3]. It was this recognition of a great potential, the tourism industry has been started in 1960's in the country [4]. The city of Gondor was found around 1636 [5] where the emperor Fasiladas decided to create his first stable capital. The city includes several touristic buildings of historical interest and that are worth visiting Gondarine architecture, religious monuments and public buildings constructed during the Italian occupation. The Fasiladas castles has been declared as a world heritage site by UNESCO in 1979 [6].

\section{Description of the Study Area}

\subsection{Location of Gondor Town}

Gondor town is located between latitude and longitude of $12^{\circ} 26^{\prime} 00^{\prime \prime} \mathrm{N}$ to $12^{\circ} 42^{\prime} 00^{\prime \prime} \mathrm{N}$ and $37^{\circ} 20^{\prime} 00^{\prime \prime} \mathrm{E}$ to $37^{\circ} 32^{\prime} 00^{\prime \prime} \mathrm{E}$ respectively and it covers an area of 40.27 square kilometers with an elevation of around 2133 meters above sea level. It was the political capital and the cultural heart of the Ethiopian highlands until the middle of the nineteenth-century. Gondor is also a noted center of ecclesiastical learning of the Ethiopian Orthodox Tewahedo Church, and known for 
having 44 ancient churches nearly many years more than any other settlement in Ethiopia.

\subsubsection{Fasil Ghebbi (Gondor)}

Figure 1(a) shown below is the view of ancient palace located in Gondor town,

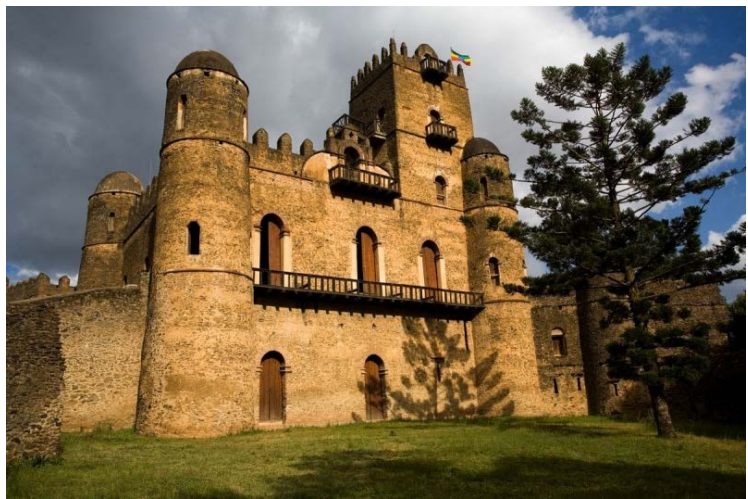

(a)

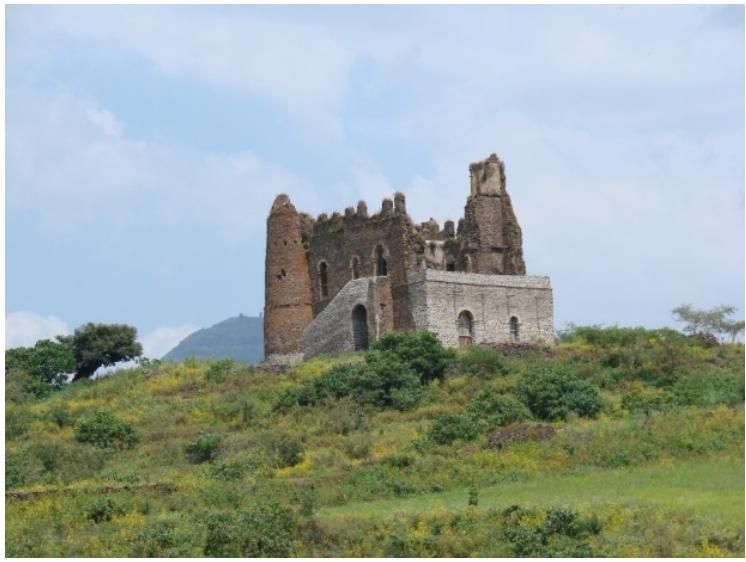

(c)

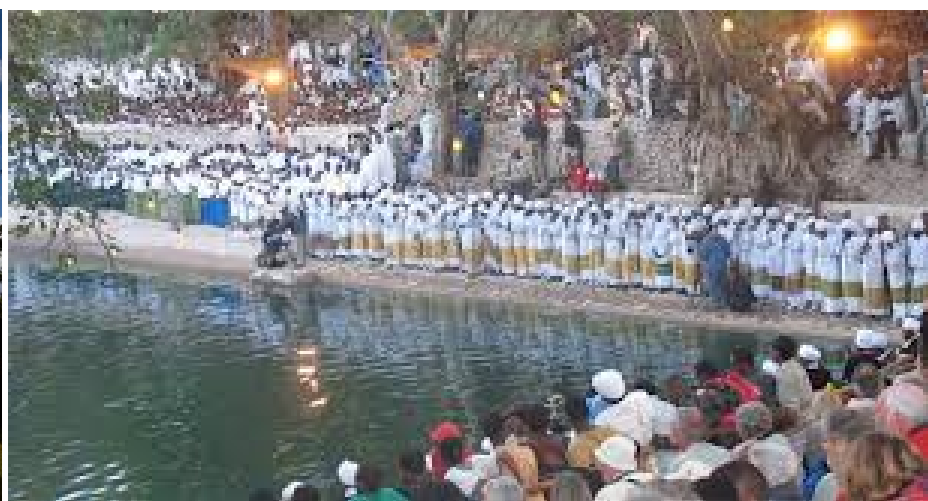

(b)

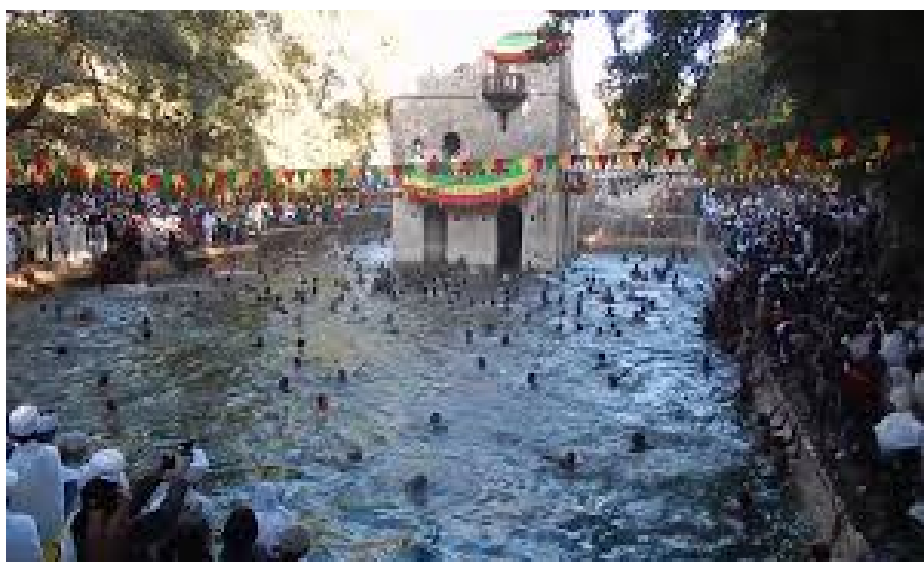

(d)

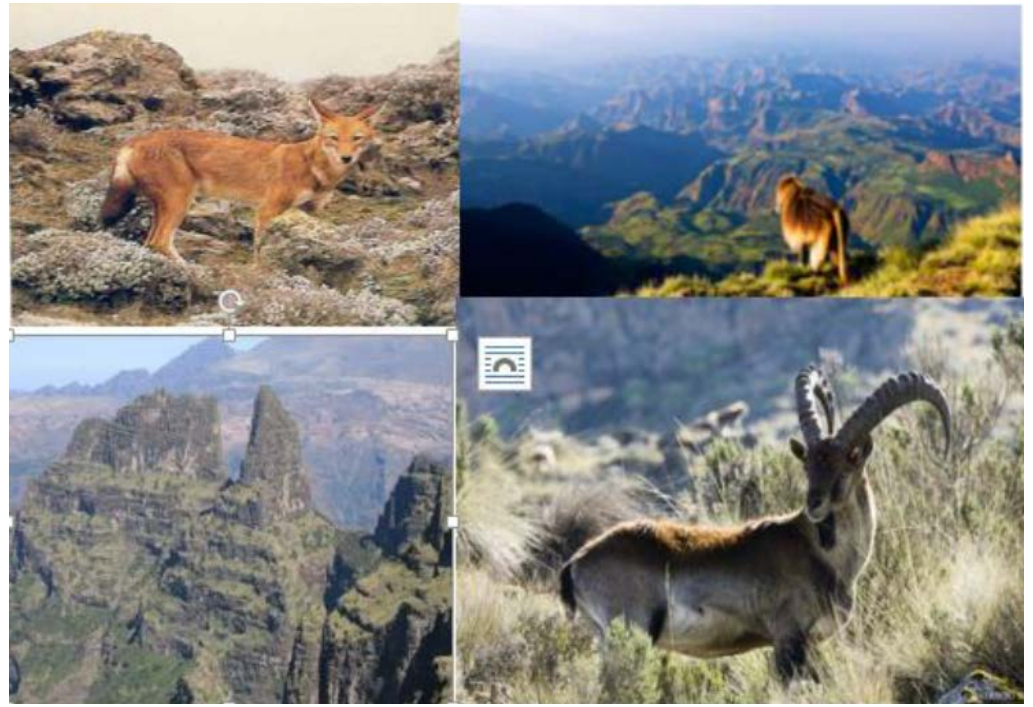

(e)

Figure 1. (a) Image of Fasil Ghebbi; (b) Epiphany in Gondor; (c) Guzara Palace; (d) Bath of Emperor Fasiladas; (e) Simien mountain national park and the beautiful endemic animal. 
Ethiopia. Gondor was the 17th century's capital of Ethiopia and it is notable for its Medieval Castles and Churches. The city's unique imperial compound contains a number of Castles built between 1632 and 1855. It served as the home of Ethiopian's emperor Fasiledes and various Emperors who ruled Ethiopia between 17th and 18th centuries. This is the only one of its kind of architecture exhibiting diverse influences including Nubian, Arab, and Baroque styles. The site was inscribed as a UNESCO world heritage site in 1979 [3]. In this compound there are fascinating historic at-tractions such as the Bath of Fasiledes (Figure 1(d)) which is famous for the celebration of Ethiopian Epiphany holiday, Fasiledes castle, lyasu's Palace, Queen Mentewab's Castle and three historical churches. The main castle which is very incredible and notable was built between 1630s and early 1640s on the orders of King Fasiledes. Fasiledes was the founder of the city of Gondor which adorned as a capital city and was responsible for the constriction of most of spectacular architectural castles in Gondor. With its huge towers and looming battlemented walls, it resembles a piece of Europe transposed to Ethiopia [7].

\subsubsection{Epiphany (Timket)}

Figure 1(b) show the greatest festival of the year celebrated on January 19 corresponding to the 10th day of Terr following the Ethiopian calendar just two weeks after the Ethiopian Christmas. It is actually a two-day event beginning on the eve of Timket with spiritual, dramatic and colorful processions. The following morning the great day itself, Christ baptism in the Jordan River by John the Baptist is commemorated. And it ends with similar activities in the eve the priest carrying the Tabot goes to back orthodox Christian church with the help of the assistant called deacon. Since January and the end of the rain, the country has been drying up steadily. The sun shines down from a clear blue sky and the festival of Timket always takes place in glorious weather [6].

\subsection{Cultural, Historical and Heritage Attractions of Surrounding Area}

\subsubsection{Simien Mountain National Park}

Simien Mountain National Park on Figure 1(e) is one of natural and historical attraction site in Northern part of Gondor and it has a spectacular landscape. The Park has a global significance for biodiversity conservation. The park is a home to endemic species, including the Iconic WaliaIbex, a wild Mountain Goat found nowhere else in the world, the Gelada Baboon and the Ethiopian Wolf. It is one of the first sites to be made a World Heritage Site by UNESCO in 1987 for Ethiopia.

The property's spectacular landscape is part of the Simien Mountain chain, which includes the highest point in Ethiopian, Ras Dashen Mountain. The rising and falling plateau of the Simien mountains has over millions of years been eroded to form precipitous cliffs and deep gorges of exceptional natural beauty. The Mountains are bounded by deep valleys to the North, East and South, and offer vast views over the rugged canyon like lowlands below. The spectacular 
scenery of the Siemen Mountains is considered to rival Colorado Grand Canyon in United States.

The Simien Mountains are the most beautiful highland plateau in Africa. Vast and exceptional, this Mountain has a spectacular skyline of rough volcanic plugs and deep gorges and channels split it. The views across the landscape are overwhelming. It is very popular for mountain trekking and watching birds as it is home to over 130 birds' species, 16 beautiful birds' species that are only found in Ethiopia. The park has over 20 different large mammal species, five small species endemic as well as an important population of the rare lammergeyer, spectacular vulture bird species [7].

\subsubsection{Guzara Palace}

The palace on Figure 1(c) is said to be Guzara palace built by Emperor Sertse Dingil, who was crowned following the death of his father, Emperor Minas, in the time between 1563 to 1597. It is situated on a Mountainous area called Guza which lies 1.5 kilo meters East of Gondar-Bahir Dar highway overlooking the sandy beach of Lake Tana. From Gondor to the turning to the palace it is about $62 \mathrm{~km}$. The palace has a stone-fenced courtyard inside which are standing a row of pillars in which its function is not known. The palace is situated a little distance from these pillars [9].

The palace was constructed with wood, stone and limestone and its architectural design had been used as a model for other palaces built in the time of emperors who came to power after Emperor Sertse Dingil. The ruins of the palace indicate that the building had special halls and rooms in its ground and the floor, an inside staircase leading to the floor and additional external stairs [8].

\section{Data and Methods}

\subsection{Data Preparation}

The collected tourist service and tourist attraction data were prepared to feed the data in QGIS software. The row primary GPS data and secondary data must organize before exporting to Arc map with a suitable excel format. The exported data is being processed in arc map and then export the data to add in QGIS software in order to change shape file data. In addition to excel location based data, all tourist service and tourist attraction data processed on a Wamp server using a proper data base format. The Figure 2 shows the hotels information record form.

In similar fashion with hotels all other tourist service and tourist attraction data is attributed in the excel sheet with a favorable GIS format. The prepared data has been loaded in arc map of arc GIS software to display with Easting and Northing data to changing excel information to shape file data. QGIS software is being one of free and open source web mapping software used in the research area. According to EPSG's projection system Gondor town and its surrounding area lays in the Adindan UTM zone 37N. After identifying the coordinate system incorporate the base map of the area based on the defined coordinate system. The 


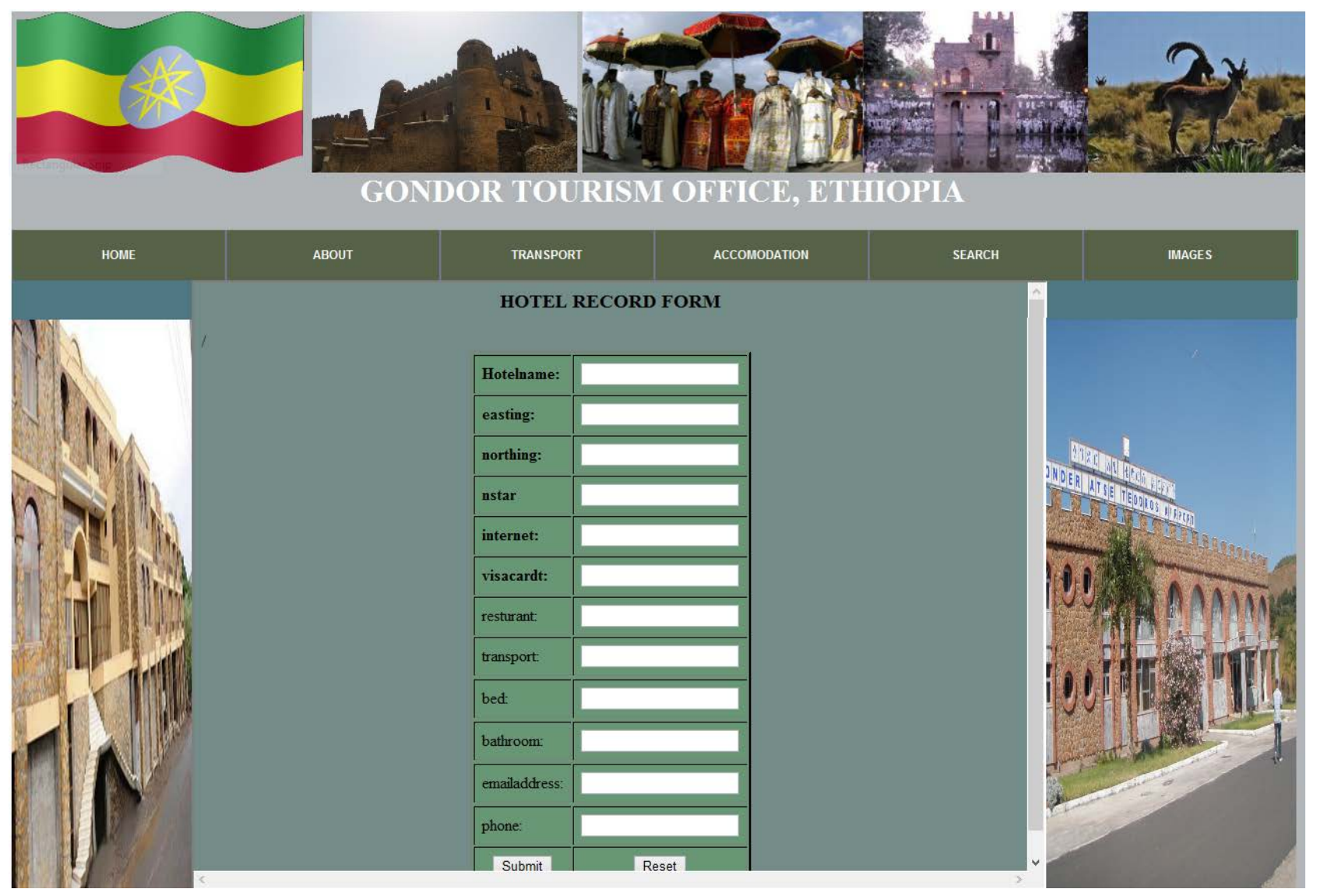

Figure 2. Result of hotel record form.

base map of the web portal was loaded from the internet using open street map QGIS plugin for referencing the web based GIS portal.

\subsection{Wamp Server}

The web based GIS for tourism development of Gondor town and surrounding area is done using well known FOSS (free and open source software) called Wamp server. Wamp server contains MYSQL as database server, PHP as application server, apache as web server, and finally operating system for delivering tabular information for tourism development in easy and readable way for peoples in the world using internet. Wamp is an acronym for Windows/Apache/MYSQL/PHP. This stack provides developer an operating system, Web server, database and Web scripting software [10] (Figure 3).

\subsection{Code Lobster}

It is a portable integrated development environment primarily (IDE) for PHP, which also supports HTML, CSS and Java script development. The program features syntax highlighting and auto-completion for PHP, HTML, CSS, and JavaScript, as well as automatic syntax checking [11]. The following Figure 4 shows the home page of Gondor town and its surrounding area tourism information $\mathrm{html}$ based programing. 


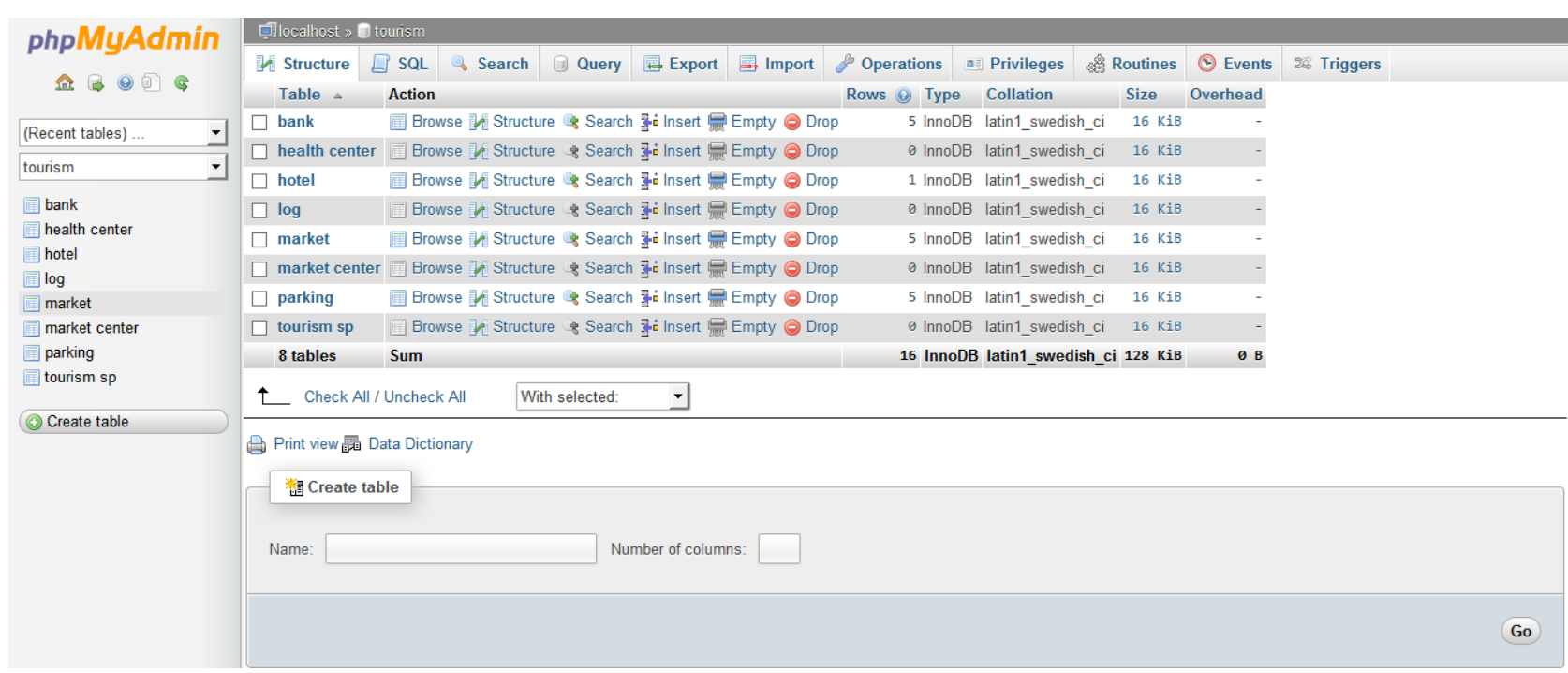

Figure 3. Sample tables in tourism database.

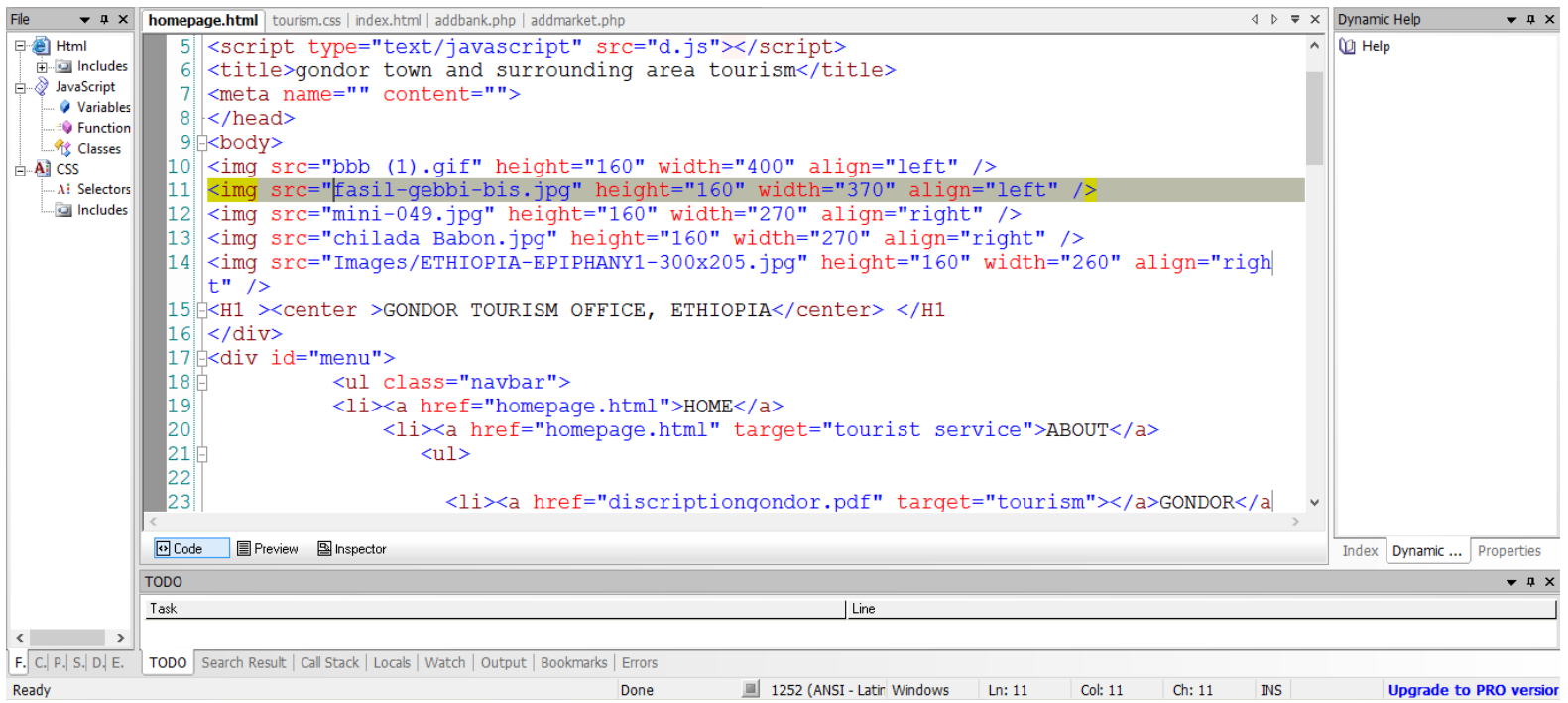

Figure 4. Php, html and CSS support programing code using code lobster Php edition.

\subsection{Server Side Scripting Language}

A scripting language allows controlling one or more software application. Scripts are different from core programming language often interpreted from source code and embedded in other applications. The popular server side scripts are PHP, ASP and JSP [13]. PHP (originally/Personal Home Page) is a one scripting languages executed on the server as opposed to client-side scripting languages like Java script programming and it used to enhance web pages. PHP can design web pages and embedded the scripting programming language. It is very often used to extract dynamic web content from a database (Figure 5).

\subsection{Client Side Scripting Language}

The client is the web interface or web browser though which the user can internet with the spatial data with Web based GIS index.html data. JavaScript is a client 
side object oriented scripting language which is popular for developing client side application. Client side scripting language is closely related with Java programming language and influenced with other programming languages but easier to program [13]. Client side scripting languages are executed in client-side by web browsers, it use the code to decide what elements to display and what data should be displayed. The following code shows default client side programing language.

<!DOCTYPE HTML PUBLIC "-//W3C//DTD HTML 4.0 Transitional//EN">

$<\mathrm{html}>$

$<$ head $>$

$<$ title $><$ title $>$

$<$ meta name="' content="'">

$</$ head $>$

$<$ body $>$

$</$ body $>$

$</$ html $>$

Figure 6 illustrates client side scripting language data flow structure.

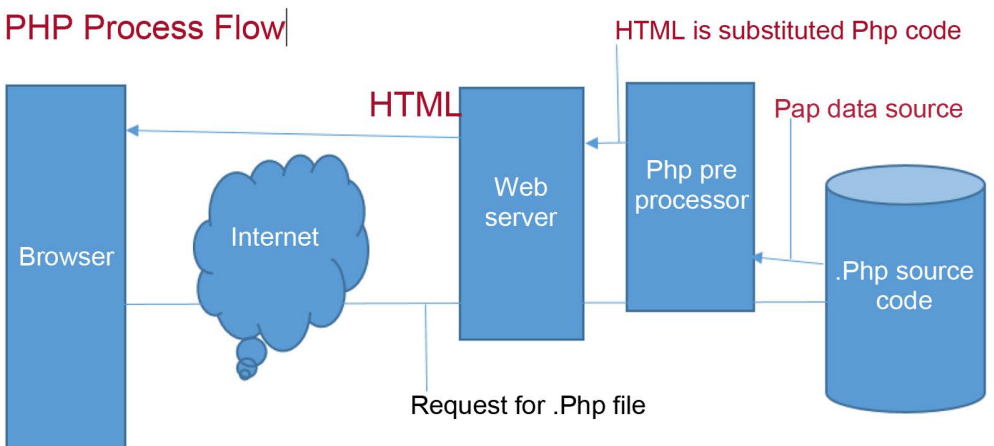

Figure 5. Php source code programing with data flow source [11].

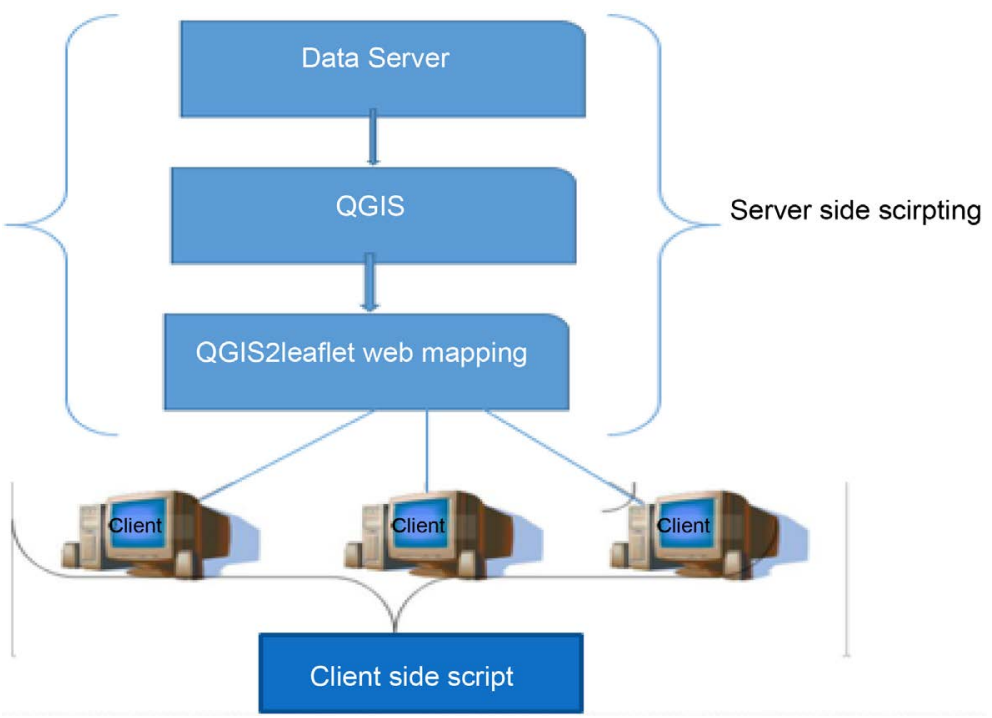

Figure 6. Client side scripting language. 


\section{Result and Discussion}

\subsection{Interface Design}

Web sites can be done by using one of programming languages (HTML, JSP, PHP, and ASP.NET). Among those languages HTML is the most basic text based programming language that has been used for web design [11]. The researcher can develop a basic web site using fundamental HTML knowledge which could be used with advanced techniques. The interface design includes the use of divisions to arrange the page layout, menu bar to link multiple pages and CSS to enhance web page element. Every time the application loads other PHP and HTML files on demand of the authorized person. The authorized person may be an individual, group of individual or tourism office of Gondor town. The web page has money HTML (hypertext mark-up language) and Cascading Style Sheet (CSS) codes used to make the web page dynamic, interactive and attractive to support tourist attraction and tourist service data of the research work. To higher up the functionality of the web site different pages have been designed and linked to the template file [11]. The template files in this research work are PHP codes to control the PHP template file and HTML code for HTML template file. The web portal has attractive interface to advert tourism industry of Gondor town and its surrounding area all over the world using World Wide Web.

\subsection{Home Page Design}

This home page (http://localhost/tourism/homepage.html) provides links to all types of information compiled under this web site using code lobster PHP edition open source software. Upper side of the home page has a tool bar with drop down menus. This tool bar includes general information about the area and tourist spots, database of the tourist services, wildlife in surrounding area and image gallery with contact tab and login form. Some information can also be accessed from the home provided at the middle of the home page. It must be supported by home page picture. The study has two pages one for the administrator and the other for the user. The administrator is an authorized person, group of individual or tourism office who they have the power to delete, update, insert and select any tourist service and tourist attraction data of the study area. The administrator page has a login to secured tourism information of the area. In the user page tourist can only view the tourist service information data such as hotel, bank, market, health Centre, transport destination, and all tourist spot with their geographic locations of the tourism information.

\subsection{Web GIS Components}

On the top side of the web based GIS portal there is a tool bar which is a GUI (Graphical User Interface) based menu bar and provides many easy to use tools to the user. These are important tools used for showing map information on the left, right, bottom and top of the home page. Also this tool indicates information about pane, zoom in, zoom out, scale bare, legend and the whole information about Google street base map and QGIS based leaflet plugin web map publication. 


\subsubsection{Search Tool bar}

Search tool bar is a very important tool, which can be used to find spatial information. This tool bar helps the user to find out any information in quick and easy way from this large database file [12]. User can get information about tourist destinations and available infrastructure by typing the name of the feature while it displays the description of the spatial feature using selection icon. This search toolbar is available on the top right corner of the home page, from where all quantum GIS based HTML documents can be found and all spatial data displayed based on the query filed. Tourists can also access linked spatial and non-spatial information with that particular tourist attraction or tourist service feature by clicking at that particular point in the homepage. In Figures 7-9 below shows the search space to find any spatial feature in the database of the web portal of Gondor town and its surrounding tourism area.

\subsubsection{Open Street Base Map}

Open source Open Street maps show all networks of the touristic area, a tourist might need to find while travelling in an unknown area. All tourist facilities are interlinked with road networks along with the spatial information about the tourist destinations. The base map of the study is on the maps of the tourist attraction and tourist service to access easily the spatial location using road networks.
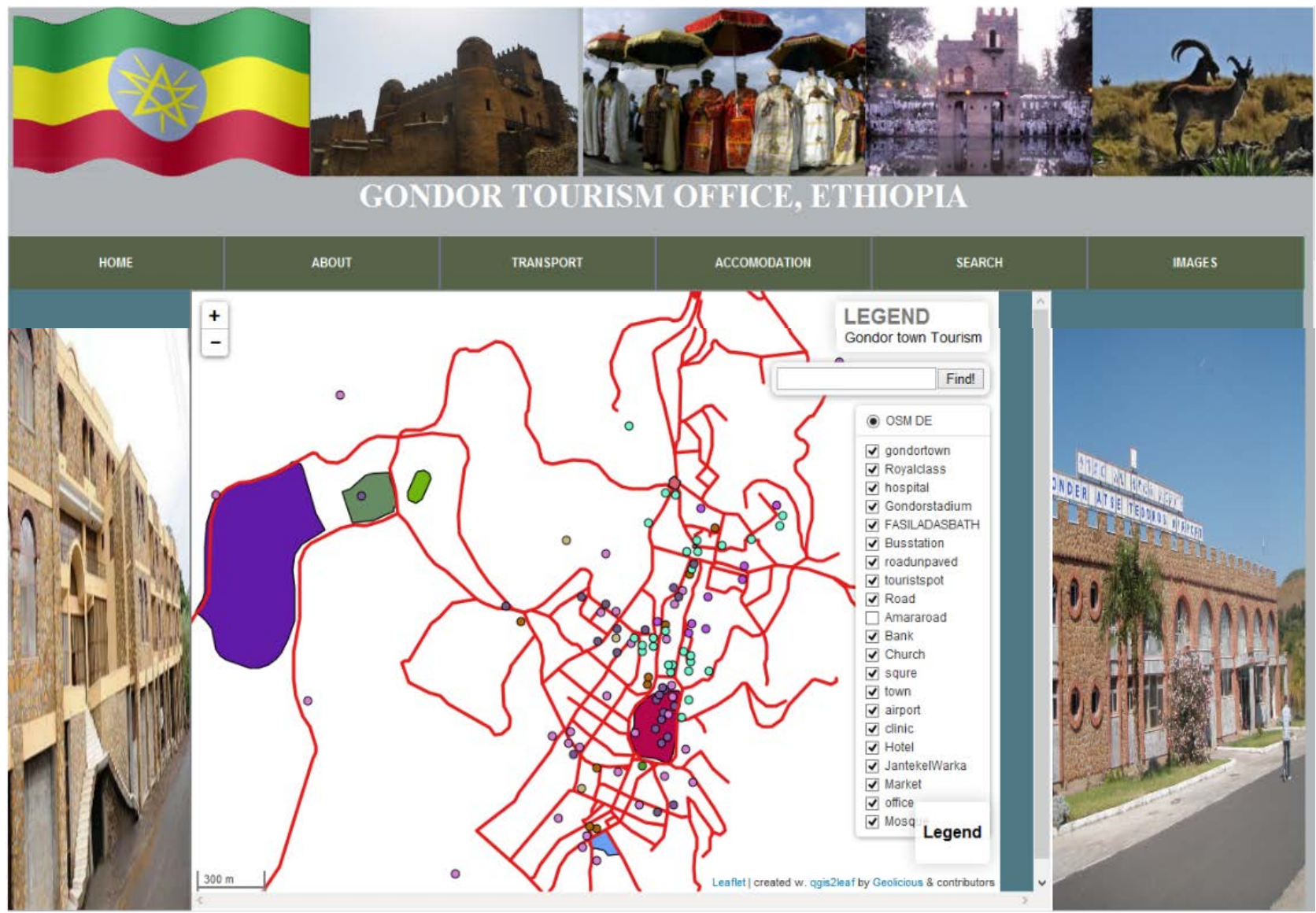

Figure 7. Web based GIS portal of the study area. 


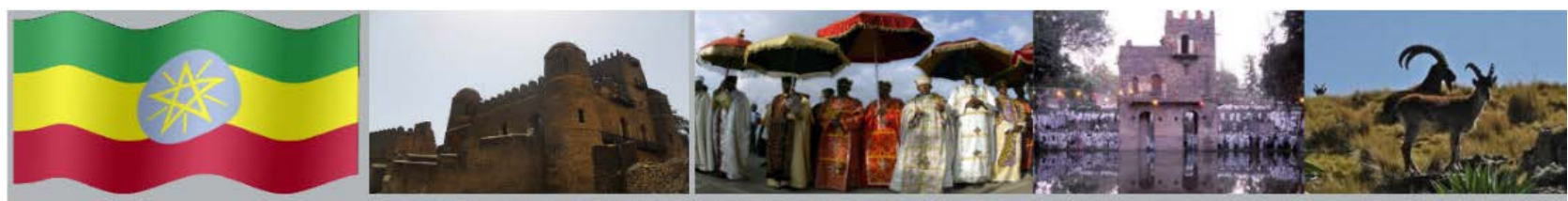

GONDOR TOURISM OFPICE, ETHIOPIA

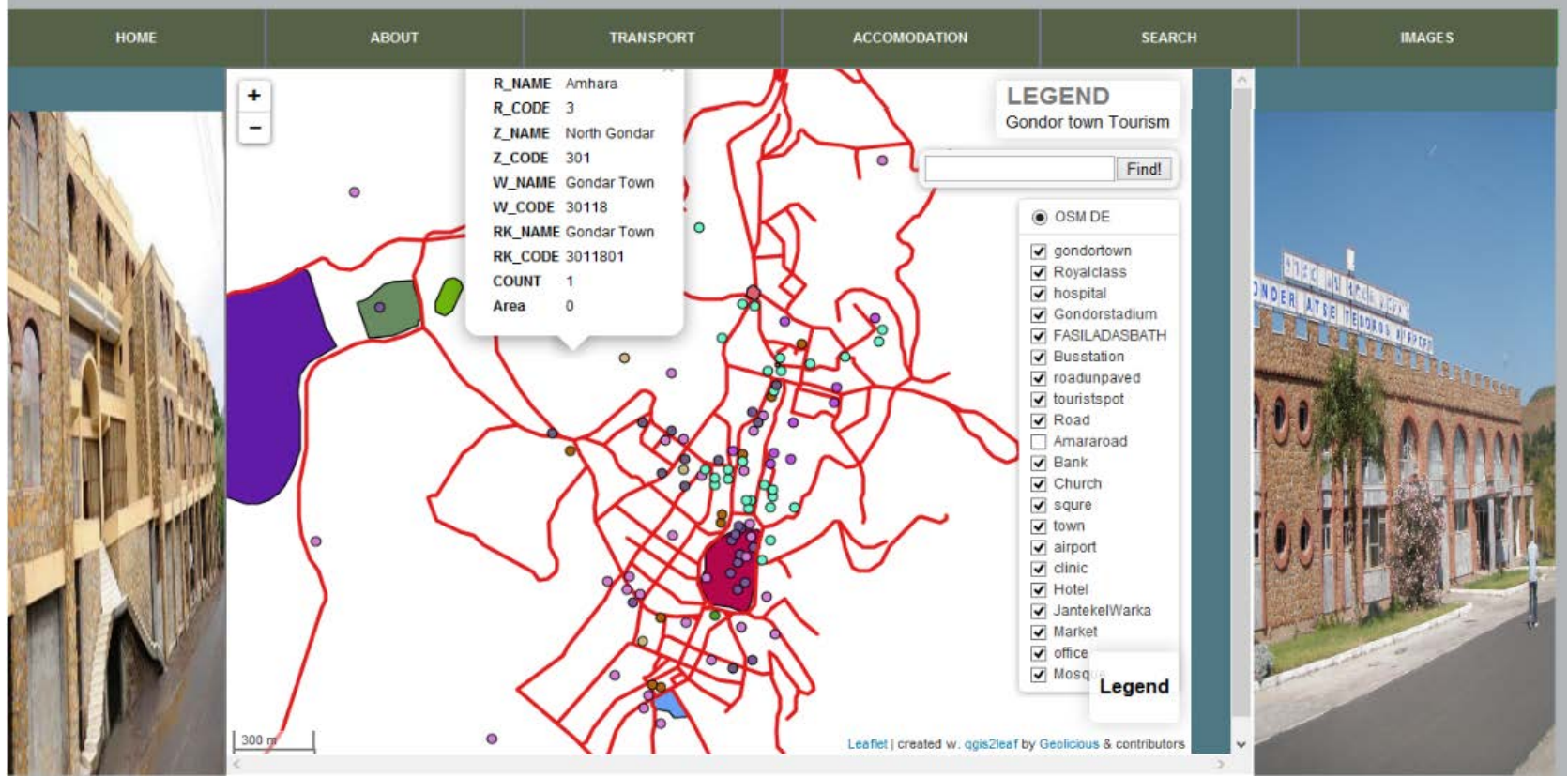

Figure 8. Sample attribute information of one feature.

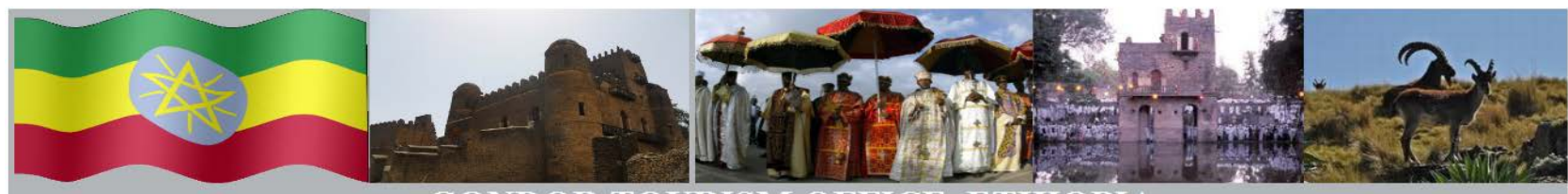

GONDOR TOURISM OFFICE, ETHIOPIA

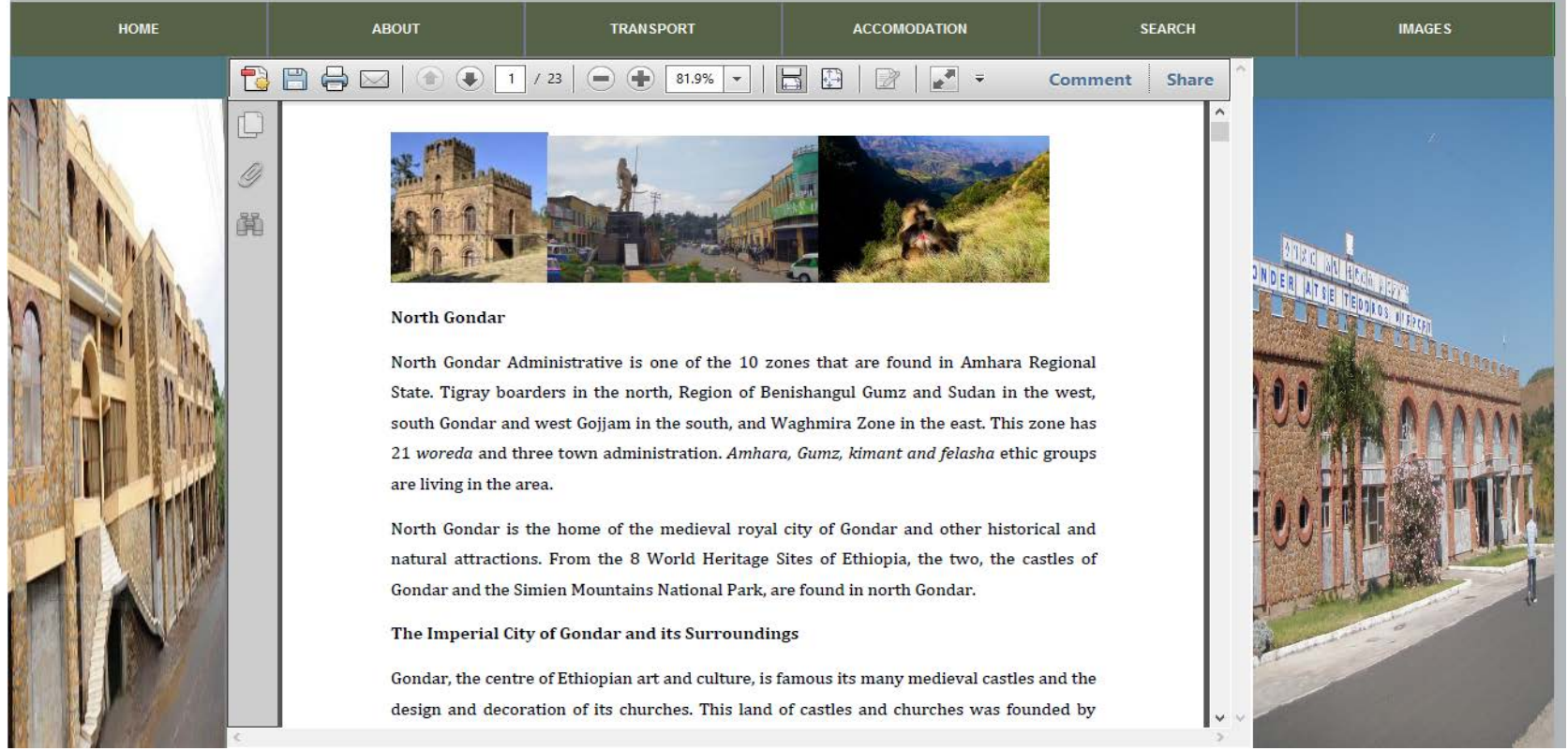

Figure 9. Tourist attraction information of the web portal. 


\section{Acknowledgements}

It is my great pleasure to extend cordial gratitude to my friend Wubetu Shiferaw and my wife Abinet Kindiefor direct and indirect contribution for the research works.

\section{References}

[1] Ioannis Pispidikis, E.D. (2015) Web Development of Spatial Content Management System through the Use of Free and Open-Source Technologies. Case Study in Rural Areas. Journal of Geographic Information System, 7, 527-540. https://doi.org/10.4236/jgis.2015.75042

[2] Simane, B. and Aseres, S.A. (2016) Development of Community-Based Ecotourism, a Case of Choke Mountain and Its Environs, Ethiopia: Challenges and Opportunities. Journal of Tourism, Hospitality and Sports, 16.

[3] Selamawit, K. (2013) Therteen Months of Sunshine: Improving Ethiopiás Image as a Tourist Destination. Centria University of Applied Sciences Unit of Technology and Business, Kokkola, May.

[4] Peng, Z. and Tsou, M. (2003) Internet GIS: Distributed Geographic Information Services for the Internet and Wireless Network. John Wiley \& Sons Inc., Hoboken.

[5] Anon (2015) Things to Do in Gonder - Virtual Tourist. www.virtualtourist.com > Travel Guides > Africa > Ethiopia > Gonder.

[6] C. C. L. Eduardo Martin Agundez, “Gondor City Tourist Map”. Ethiopian Mapping Agency, Spain, 2013

[7] UNESCO.

https://www.google.com.et/?gws_rd=cr\&ei=ReVBVoWmF8eysQGHrZb4CA\#q=Fas $\mathrm{il}+$ Ghebbi $\% 2 \mathrm{C}+$ Gondar+Region+\%E2\%80\%93+UNESCO+World+Heritage+Centr

[8] Ministry of Cultural \& Tourism (2015) North Gondor Zone Tourism, Amahera. Ethiopia.

[9] Ministry of Culture \& Tourism (2015) North Gondor Zone Tourism, Amahra Region. Ethiopia.

[10] Agrawal, S. and Gupta, R. (2014) Development and Comparision of Open Source Based Web GIS Frameworks on WAMP and Apache Tomcat Web Server. International Archives of the Photogrammetry, Remote Sensing and Spatial Information Sciences, XL-4, 1-5. https://doi.org/10.5194/isprsarchives-XL-4-1-2014

[11] Google (2015). https://www.tutorialspoint.com

[12] Nutan, T. (2014) Web GIS Application for Customized Tourist Information System for Eastern UP. Journal of Geomatics, 8, 1-6.

[13] Abel, M. (2014) The Role of Web GIS in the Tourism Development-In Case of Bahirdar Town and Surrounding Area, Amahra Region, Ethiopia. Radix International Journal of Research in Social Science, 3. 
Submit or recommend next manuscript to SCIRP and we will provide best service for you:

Accepting pre-submission inquiries through Email, Facebook, LinkedIn, Twitter, etc. A wide selection of journals (inclusive of 9 subjects, more than 200 journals)

Providing 24-hour high-quality service

User-friendly online submission system

Fair and swift peer-review system

Efficient typesetting and proofreading procedure

Display of the result of downloads and visits, as well as the number of cited articles Maximum dissemination of your research work

Submit your manuscript at: http://papersubmission.scirp.org/

Or contact jgis@scirp.org 